\title{
A CASE OF PEMPHIGUS VULGARIS DEVELOPED DURING PREGNANCY
}

\author{
Jong-Soo Kim, MD, Su-Kon Kim, MD \\ Department of Obstetrics and Gynecology, Dankook University College of Medicine, Cheonan, Korea
}

Pemphigus vulgaris is an uncommon, autoimmune disease characterized by acantholysis and blister formation in the skin and mucosa. Pemphigus vulgaris during pregnancy is exceedingly rare. The disease may be associated with adverse neonatal outcome, including prematurity and fetal death. The clinical features of this patient were similar to those of pemphigoid gestationis. Circulating antibodies directed at desmosomal proteins may cross the placenta and place children at risk for neonatal pemphigus. Transient skin lesions may occasionally appear in the neonate. We report a case of pemphigus vulgaris in a 32-yearold pregnant woman who showed erythematous bullae, erosions and crusts on the whole body. She was diagnosed by clinical and histopathological findings, direct immunofluorescent test. This patient was treated with high dose of corticosteroids to control the disease.

Keywords: Pemphigus; Autoimmune diseases; Pregnancy

천포창은 수포성 피부질환 중의 하나로서 피부와 점막의 표피세포 간질(intercellular space)에 대한 자가항체를 가지는 자가면역질환으로 알려져 있다[1]. 이러한 천포창은 미국 일부지역의 통계에 의하면 연간 발병률이 인구 10 만 명 중 0.5 명으로 드물며[2], 그중 심상성 천포창은 전체 천포창 환자의 약 $70 \%$ 가 되는 것으로 보고되고 있다. 임신 시 발 생한 본 증례의 경우는 매우 드물다고 알려져 있으며[3] 국내 피부과 문헌상에 단 1예만이 보고되고 있을 뿐이다[4]. 천포창은 치료하지 않 을 경우 사망률이 높은 위중한 피부병이기 때문에 적절한 치료가 매우 중요하다. 본 저자들은 임신 37주에 임상적으로는 임신성 유천포창과 감별이 어려웠으나 병리조직학적으로 전형적인 심상성 천포창의 소견 을 보이는 환자에서 immunoglobulin $\mathrm{G}(\mathrm{gGG})$ 자가항체를 증명함으로써 임신 중에는 매우 드물게 발생되는 심상성 천포창으로 1 예 경험하였기 에 문헌 고찰과 함께 보고하는 바이다.

\section{증 례}

환 자: 전 0 O, 32세, 여자

산과력: 1-0-0-1

과거력: 특이사항은 없었다.

가족력: 특이사항은 없었다.

주 소: 소양감을 동반한 전신의 두드러기양 및 수포성 발진.

현병력: 환자는 임신 $36+3$ 주로 약 1개월 전부터 배꼽부위부터 시작된 심한 소양감을 동반한 두드러기양 발진 및 수포가 발생하여 내원하였다.
이학적 소견: 내원 당시 의식은 명료하였으며, 혈압은 $130 / 90 \mathrm{~mm} \mathrm{Hg}$, 맥박 $76 /$ 분, 체온 $36.4^{\circ} \mathrm{C}$, 호흡은 $16 /$ 분이었으며, 피부 병변 이외에 특 이한 소견은 없었다.

검사 소견: 혈액검사상 혈색소 $11.7 \mathrm{~g} / \mathrm{dL}$, 헤마토크릿 $35.03 \%$, 백혈 구 $10,270 / \mu \mathrm{L}$, 혈소판 $307,000 / \mu \mathrm{L}$ 이었다. 그 외 간 기능, 전해질, 소 변검사는 정상 소견을 보였다. 심전도검사, 흉부 및 복부 방사선 소견 등 이외의 검사에서 특이 소견을 보이지 않았다. Herpes simplex virus 항체에 대한 혈청검사상 $\operatorname{lgG}$ 는 양성, immunoglobulin $\mathrm{M}(\mathrm{lgM})$ 은 음성, varicella zoster virus 항체에 대한 혈청검사상 $\operatorname{lgG}$ 는 양성, $\operatorname{lgM}$ 은 음성 이었으며, 자가항체검사상 류마티스 인자rheumatoid factor와 항핵항 체(antinuclear antibody)는 음성이었다.

Received: 2011. 5.30. Revised: 2011. 9.28. Accepted: 2011.10.12. Corresponding author: Su-Kon Kim, MD

Department of Obstetrics and Gynecology, Dankook University College of Medicine, 359 Manghyang-ro, Dongnam-gu, Cheonan 330-715, Korea

Tel: +82-41-550-6159 Fax: +82-41-556-3878

E-mail: euphorius@naver.com

This is an Open Access article distributed under the terms of the Creative Commons Attribution Non-Commercial License (http://creativecommons.org/licenses/ by-nc/3.0/) which permits unrestricted non-commercial use, distribution, and reproduction in any medium, provided the original work is properly cited.

Copyright $\odot$ 2011. Korean Society of Obstetrics and Gynecology 


\section{KOREAN JOURNAL OF OBSTETRICS \& GYNECOLOGY}

Jong-Soo Kim, et al. Pemphigus vulgaris, pregnancy

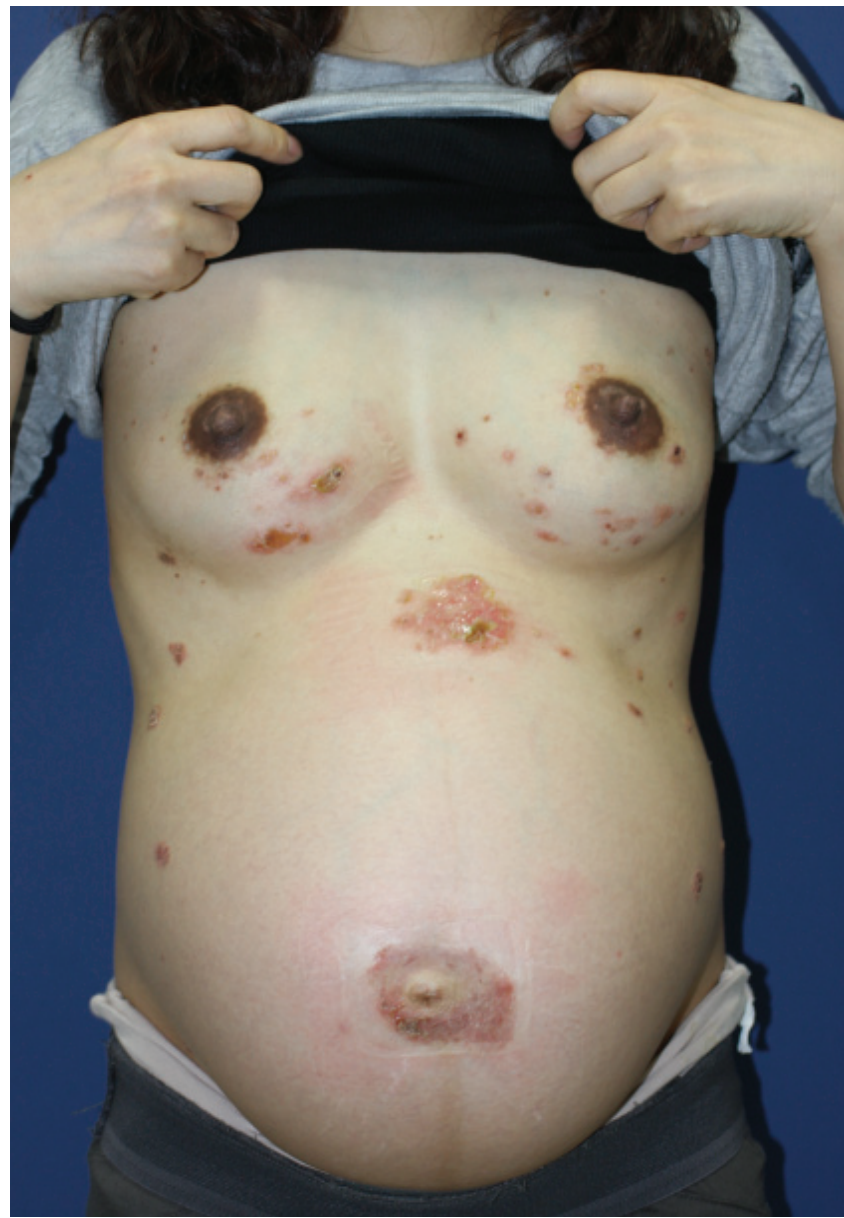

Fig. 1. Multiple erythematous to dark red, annular or targetoid macules and plaques on the abdomen, especially around the umbilicus.

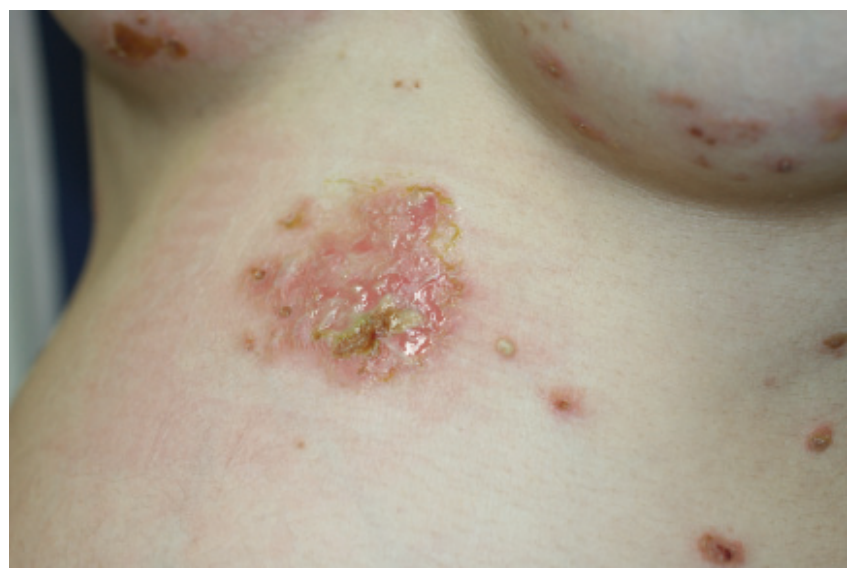

Fig. 2. Multiple tense vesicles and bullae on the erythematous base in the abdomen.

피부 소견: 복부 및 유방과 등에 홍반성 두드러기양 판이 발생되었고 판의 주변에 환상으로 수포가 발생되었으며(Figs. 1, 2), 얼굴과 점막부 위에는 병변의 침범이 없었다.

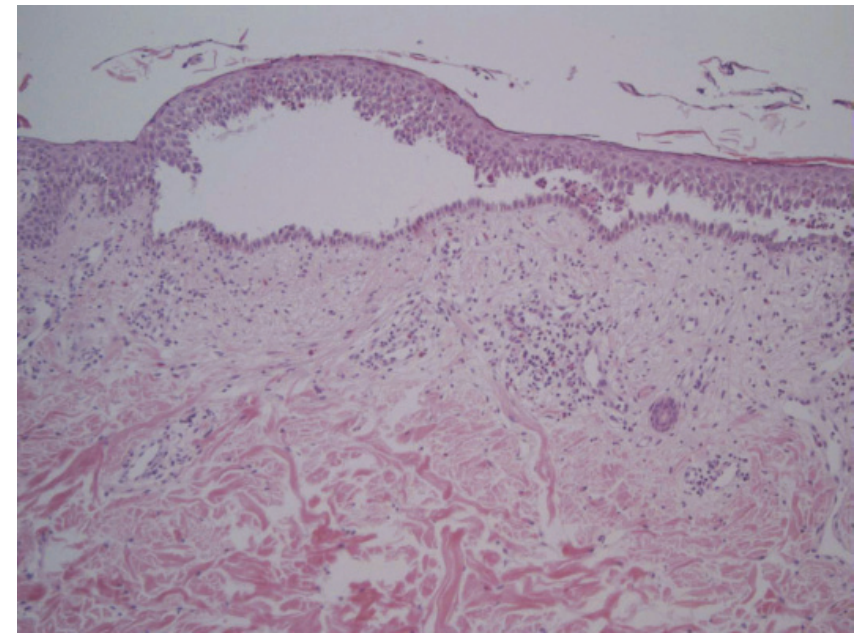

Fig. 3. An intraepidermal acantholytic blister has a suprabasal cleavage plane. Severe edematous change in the papillary dermis and inflammatory cell infiltration admixed with considerable amount of eosinophilis ( $\mathrm{H} \& \mathrm{E}$, $\times 100)$

병리학적 소견: 환자 등의 병변주위에서 시행한 피부 생검 소견에서 표피하 수포와 함께 표피내 경한 세포외 유출 및 해면화와 유두진피의 심한 부종이 발견되었다. 진피의 혈관 주위로 주로 호중구와 호산구의 침윤이 보였다(Fig. 3).

면역형광검사: 직접면역형광검사에서 표피세포 사이에 C3, lgG가 관 찰되었다(Fig. 4).

치료 및 경과: 입원 당시 부신피질 호르몬제(prednisolone, $20 \mathrm{mg} /$ day)와, 항히스타민제를 경구 투여하였다. 환자는 입원 11일째인 2011 년 3월 14일에 유도분만으로 $2.51 \mathrm{~kg}$ 의 건강한 여아를 정상분만하였 다. 경구 투여로 병변의 소실과 증상이 호전되었고, 퇴원한 후 외래 통 원 치료 시는 부신피질 호르몬제(methylprednisolone, $20 \mathrm{mg} /$ day)과 면역억제제(mycophenolate, $1,000 \mathrm{mg} / \mathrm{day}$ )를 1주일간 유지한 후 투 약을 중지하였으며 추후 피부 병변 재발은 없었다.

\section{고 찰}

임신이란 대사적, 면역학적, 내분비적으로 많은 변화를 초래하는 독 특한 생리적 상태로 피부와 점막 및 피부 부속기에도 많은 변화를 초래 한다.

천포창은 피부와 점막에 수포를 형성하는 수포성 질환으로서 조직 학적으로 각질형성세포와 각질형성세포 사이의 결합이 풀어지는 현상, 즉 극세포해리(acantholysis)를 특징으로 하는 질환이다. 대부분의 환 자는 혈청내에 각질형성세포 표면에 존재하는 항원에 대한 자가항체 를 가지고 있으며 이 자가항체가 천포창의 발병에 직접 관여한다는 점 에서 대표적인 자가항체에 의한 자가면역질환이라고 할 수 있다. 심상 성 천포창은 모두 50-60세 사이에서 호발하며 남녀 간의 발생 차이 


\section{KOREAN JOURNAL OF OBSTETRICS \& GYNECOLOGY}

KJOG Vol. 54, No. 12, 2011
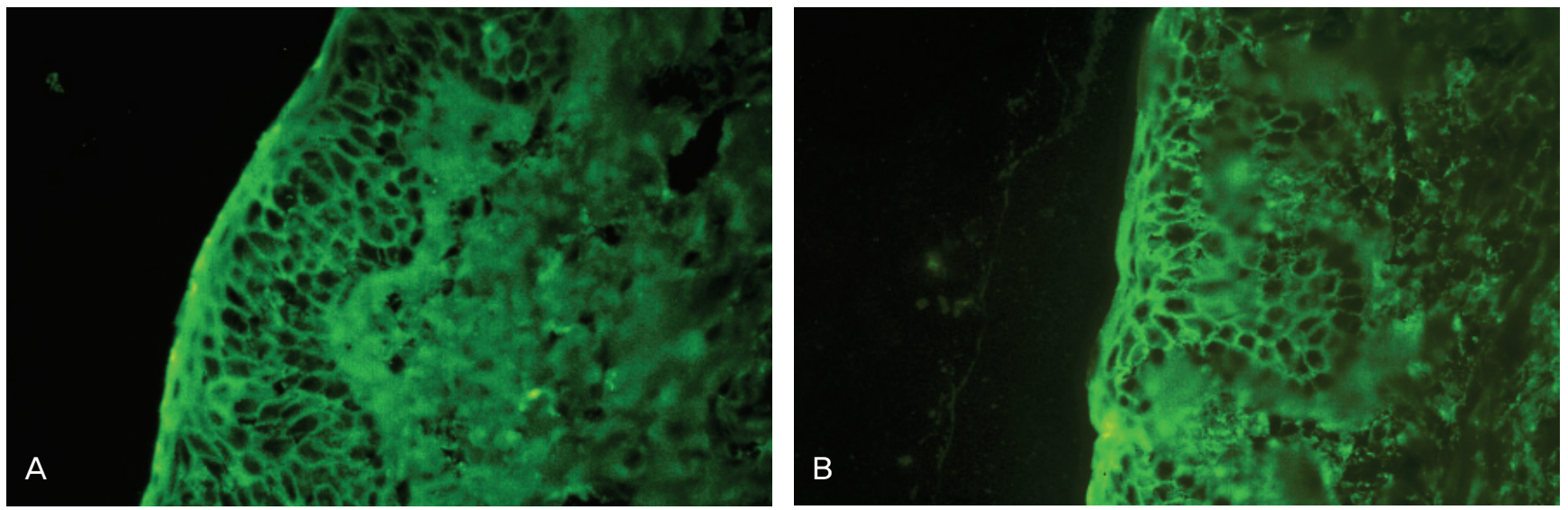

Fig. 4. There is lace-like squamous intercellular space deposition of $C 3(A)$, immunoglobulin $G(B)$ in the epidermis (direct immunofluorescence, $\times 200$ ).

는 없다. 심상성 천포창의 발생빈도는 인종에 따라 차이를 보여 유대 인에서 발생빈도가 높아 예루살렘에서는 인구 10만 명당 1년에 1.6 명 으로 보고되고 있으며, 유대인이 적은 핀란드에서는 인구 10만 명당 1 년에 0.76명 보고되고 있다[1]. Lee [5]의 보고에 의하면 천포창이 한 국에서는 가장 흔한 자가면역성 수포성 질환으로, 인구 10 만 명당 1년 에 0.1-0.5명 정도로 발생한다고 하였으나, 아직까지 우리나라에서 천 포창의 유병률에 대한 정확한 통계는 없다. 임신 시 천포창이 발생하는 것은 극히 드물다고 알려져 있다[3].

심상성 천포창은 가장 흔한 천포창으로서 피부와 점막에 수포가 발 생하는 질환이다. 대부분의 환자가 구강점막에서부터 병변이 시작되 며, 수주나 수개월 후 피부에도 수포가 발생하고 적절한 치료를 하지 않을 경우 전신에 번져 사망하게 되는 질환이다. 심상성 천포창은 발 병 초기에 환자의 약 50-70\% 정도에서 구강점막에서 처음 병변이 발 생하며[6], 병이 경과함에 따라 약 80-90\%에서 구강점막에 병변이 나 타난다고 한다[7]. 구강점막 외에도 비강점막, 인후두, 식도, 안부결막, 요도, 외음부, 직장 항문부와 같은 중층편평상피로 구성된 점막부에 본 질환의 병변이 발생할 수 있다[8].

Nikolsky 징후는 수포주변 정상피부를 문지르면 쉽게 피부가 벗겨지 는 현상 또는 수포 위를 누르면 수포가 주변으로 확대되는 현상을 말하 는데 이 징후는 심상성 천포창에서 가장 잘 볼 수 있지만 유천포창에서 도 볼 수 있다. 임상적으로 수포 발생부위나 모양 또는 소양감의 정도 등의 소견만으로 심상성 천포창과 임신성 유천포창을 감별하기는 쉽지 않다. 그러나 전형적인 경우를 생각해보면 임신성 유천포창은 비교적 긴장성의 구진성 수포가 복부를 중심으로 나타나고 심한 소양감을 동 반하며 구강점막에서는 수포성 병변은 비교적 드물다. 심상성 천포창 의 경우는 이완성 대수포가 두부, 흉부, 복부 또는 사지의 굴절 부위에 발생하며, 심한 소양감은 호소하지 않고 구강점막에 수포성 병변이 흔 히 발생한다.

심상성 천포창의 병리 소견은 기저세포층 바로 위 극세포 해리증으 로 인한 수포가 보이며 수포내에는 둥근 극세포 해리세포들이 떠 있 는 것을 볼 수 있다. 기저세포는 양옆의 기저세포와 위쪽의 각질 형성
세포와는 결합이 풀어져 있지만 진피와의 결합은 정상적이므로 기저세 포가 마치 비석이 줄지어 서있는 듯한 모양을 보이는데 이를 "row of tombstones"라 하며 심상성 천포창의 특징적인 조직 소견이다(Fig. 3). 면역형광검사상 표피세포간질에 $\operatorname{lgG}$ 와 C3 보체 침착이 관찰되며, 자가 항체는 desoglein 1 인 $160 \mathrm{KD}$ 의 당단백에 결합한다. 본 증례의 경우 임상양상은 심한 소양감과 구강점막에 수포성 병변이 생기지 않은 점 과 점막부위 침범이 없는 것으로 보아 임신성 유천포창의 가능성이 높 다고 생각되었다. 그러나 조직검사상 극세포 해리가 기저세포층 바로 위에 발생하였고, 직접면역형광검사상 유천포창에서는 일반적으로 C3 과 $\operatorname{lgG}$ 가 기저막대를 따라 선상으로 침윤되는 반면 천포창에서는 표피 세포간질에 $\operatorname{lgG}$ 및 C3가 침착된다고 알려져 있는데, 본 증례에서는 피 부기저막대에는 특별한 소견이 없으며, 표피세포간질에 $\operatorname{lgG}$ 및 C3가 침착되어 천포창으로 확진할 수 있었다(Fig. 4).

모체로부터의 심상성 천포창 $\operatorname{lgG}$ 의 태반을 통한 태아로의 전달은 신 생아에서 임상적 징후를 나타나게 한다[9]. 그러나 일반적으로 신생아 의 심상성 천포창은 성인이 될 때까지 지속되지 않으며, 대부분의 피부 병변은 자연적으로 3 주 내에 좋아지는 경향을 보인다[10]. 또한 심상성 천포창은 조기진통이나 태아 발육지연 등 임신중 태아에 다른 영향을 미칠 수 있다.

부신피질호르몬제가 치료에 사용되기 전인 1950년대에는 발병 2년 에 사망률이 $50 \%$ 였고 5 년까지는 거의 대부분이 사망하게 되는 매우 예후가 나쁜 질환이었다. 그러나 현재 사망률은 약 $5 \%$ 정도이며 가장 흔한 사망원인은 패혈증인데 대부분 면역억제치료의 부작용에 의한 것 이다. 그 이후 면역억제제 등의 보조요법을 사용한 이후에는 더욱 감소 하였다[11]. 이에는 여러 요인이 있겠지만, 면역억제제의 사용으로 치 료효과를 높이면서 부신피질호르몬제의 사용량을 줄여 부신피질호르 몬제에 의한 부작용을 감소시켰기 때문에 사망률이 낮아진 것으로 생 각할 수 있다.

임신 시 발생하는 본 증례의 치료에서 고용량의 부신피질호르몬을 임신 12주 이전에 투여 시 태아에게 구개열 등의 기형이나, 자궁내 성 장지연을 일으킬 수 있으나 임신 12주 이후에 사용하는 것은 비교적 


\section{KOREAN JOURNAL OF OBSTETRICS \& GYNECOLOGY}

Jong-Soo Kim, et al. Pemphigus vulgaris, pregnancy

안전하다고 알려져 있으며, 면역억제제의 사용은 면역기능저하와 태아 기형을 유발시킬 수 있어 투여해서는 안되고, 부신피질호르몬에 내성 을 보이는 경우는 혈장교환술(plasmaphresis)을 실시할 수 있다[12].

본 증례에서는 부신피질호르몬제(prednisolone, $20 \mathrm{mg} /$ day)와, 항 히스타민제를 경구 투여하여 임상적 호전이 관찰되었으며, 퇴원한 후 외래 통원 치료 시는 부신피질 호르몬제(methylprednisolone, $20 \mathrm{mg} /$ day)과 면역억제제(mycophenolate, $1,000 \mathrm{mg} / \mathrm{day}$ )를 유지할 수 있었 다. 추후 피부 병변의 재발은 없었다.

본 증례는 배꼽 주위의 복부를 중심으로 발생한 홍반성 반 및 수포 등의 피부 소견, 점막을 침범하지 않는 임상경과는 임신성 유천포창에 부합하나, 상부 진피의 부종과 호산구의 침윤이 특징인 피부생검 조직 소견, 그리고 면역형광검사상 표피세포간질에 $\operatorname{lgG}$ 및 C3가 침착되어 확진한 특이한 임신 중에 발생한 심상성 천포창으로 생각되며 한국인 에서는 드문 질병이기에 보고하는 바이다.

\section{References}

1. Stanley JR. Pemphigus. In: Freedberg IM, Eisen AZ, Wolff $K_{\text {, }}$ Austen KF, Goldsmith LA, Katz SI, editors. Fitzpatrick's dermatology in general medicine. 6th ed. New York: McGraw-Hill; 2003. p.558-67.

2. Lynch PJ, Gallego RE, Saied NK. Pemphigus -- a review. Ariz Med 1976;33:1030-7.

3. Terpstra $H$, de Jong $M C$, Klokke $A H$. In vivo bound pemphigus antibodies in a stillborn infant. Passive intrauterine transfer of pemphigus vulgaris? Arch Dermatol 1979;115:316-9.

4. Lee CW, Kim SH, Yu HJ. Pemphigus vulgaris developed during pregnancy. Korean J Dermatol 1981;19:99-103.

5. Lee CW. Autoimmune disease of the skin. Seoul: Academia; 2002

6. Pisanti S, Sharav Y, Kaufman E, Posner LN. Pemphigus vulgaris: incidence in Jews of different ethnic groups, according to age, sex, and initial lesion. Oral Surg Oral Med Oral Pathol 1974;38:382-7.

7. Korman N. Pemphigus. J Am Acad Dermatol 1988;18:1219-38.

8. Kaplan RP, Touloukian J, Ahmed AR, Newcomer VD. Esophagitis dissecans superficialis associated with pemphigus vulgaris. J Am Acad Dermatol 1981;4:682-7.

9. Wasserstrum N, Laros RK Jr. Transplacental transmission of pemphigus. JAMA 1983;249:1480-2.

10. Chowdhury MM, Natarajan S. Neonatal pemphigus vulgaris associated with mild oral pemphigus vulgaris in the mother during pregnancy. Br J Dermatol 1998;139:500-3.

11. Harman KE, Albert S, Black MM; British Association of Dermatologists. Guidelines for the management of pemphigus vulgaris. Br J Dermatol 2003;149:926-37.

12. Virgili A, Corazza M, Vesce F, Garutti P, Mollica G, Califano A. Pemphigus in pregnancy. Acta Derm Venereol 1995;75:172-3.

\section{임신 중 발생된 심상성 천포창 1예}

\section{단국대학교 의과대학 산부인과학교실}

김종수, 김수곤

심상성 천포창은 드물며 극세포 해리와 피부 및 점막에 수포형성이 특징인 자가면역질환이다. 임신 중의 심상성 천포창은 매우 드물며 이 질환은 본 질환은 태아사망이나 조기분만 등의 다른 주산기 결과와 연관될 수 있다. 본 환자에서 임상적 양상은 임신성 유천포창과 매 우 유사하였다. 교소체의 단백질에 대한 순환 항체는 태반을 건너갈 수 있고, 신생아 천포창에 대한 위험을 높일 수 있으며, 일시적 피부병 변이 신생아에게서 나타날 수 있다. 저자들은 전신에 발생한 홍반성 수포 및 미란과 가피를 주소로 내원한 32세의 산모에서, 병변을 임상 적, 병리조직학적 소견과 직접면역형광검사로 진단하였으며, 고용량의 부신피질 호르몬으로 치료하였기에 보고하는 바이다.

중심단어: 천포창, 자가면역질환, 임신 